УДК 550.422

ОПРЕДЕЛЕНИЕ ОСТАТОЧНЫХ КОЛИЧЕСТВ НЕФТЕПРОДУКТОВ

И ВОДОРАСТВОРИМЫХ МИНЕРАЛЬНЫХ ЗАГРЯЗНИТЕЛЕЙ В ПОЧВОГРУНТАХ УРБАНИЗИРОВАННЫХ ТЕРРИТОРИЙ

\author{
${ }^{1}$ Лукашов С.В., ${ }^{1}$ Надточей Е.П., ${ }^{2}$ Иванченкова О.А. \\ ${ }^{1}$ ФГБОУ ВО «Брянский государственный университет им. акад. И.Г. Петровского», \\ Брянск, e-mail: sergelukashov@yandex.ru; \\ ${ }^{2}$ ФББОУ ВО «Брянский государственный инженерно-технологический университет», \\ Брянск, e-mail: oa-iva79@mail.ru
}

\begin{abstract}
В данной работе проанализированы подходы к классификации и описанию химического состава нефтепродуктов и водорастворимых минеральных загрязнителей почвогрунтов. Обосновано выделение основных источников загрязнения почвогрунтов нефтепродуктами, бенз-а-пиреном и водорастворимыми минеральными солями. Выполнена сравнительная оценка методов определения суммарного содержания нефтепродуктов, определения остаточных количеств бенз-а-пирена и водорастворимых неорганических загрязнителей почвогрунтов урбанизированных территорий. Предложены критерии выбора оптимальных физико-химических методов количественного определения нефтепродуктов и минеральных загрязнителей в почвогрунтах. Усовершенствована методика количественного определения суммарного содержания нефтепродуктов в почвогрунтах. Показано, что предлагаемая нами методика отвечает требованиям экспрессности и позволяет определять суммарное содержание нефтепродуктов в различных типах почвогрунтов урбанизированных территорий. Достоверность предложенной методики доказана методами математической статистики. Определень остаточные количества нефтепродуктов, бенз-а-пирена, хлоридов, фосфатов и сульфатов в почвогрунтах, отобранных в четырех различных зонах урбанизированных территорий. Остаточные количества бенз-а-пирена определены методом высокоэффективной жидкостной хроматографии. Пробы для определения остаточных количеств бенз-а-пирена подготавливали по оригинальной методике: очищали на смеси окиси алюминия и сульфата натрия, элюирование проводили гексано-хлористометиленовой смесью. На конкретных примерах рассмотрено определение массовой концентрации ионов хлорида, сульфата и фосфата в пробах почвогрунтов (водорастворимая форма) методом ионной хроматографии. Результаты исследований были проанализированы в соответствии с нормируемыми показателями допустимого содержания в почвогрунтах по каждому виду загрязнителей. Показано, что полученные данные могут быть положены в основу экологического мониторинга почвогрунтов урбанизированных территорий с целью прогнозной оценки перспектив их использования.
\end{abstract}

Ключевые слова: нефтепродукты, почвогрунт, урбанизированная территория, бенз-а-пирен, минеральные загрязнители, нормируемые показатели, экологический мониторинг

\title{
DETERMINATION OF RESIDUAL AMOUNTS OF PETROLEUM PRODUCTS AND WATER-SOLUBLE MINERAL POLLUTANTS IN THE SOILS OF URBANIZED TERRITORIES
}

${ }^{1}$ Lukashov S.V., ${ }^{1}$ Nadtochey E.P., ${ }^{2}$ Ivanchenkova O.A.

${ }^{1}$ Bryansk State University named after acad.I.G. Petrovskiy, Bryansk, e-mail: sergelukashov@yandex.ru; ${ }^{2}$ Bryansk state engineering-technological University, Bryansk, e-mail: oa-iva79@mail.ru

In this paper, we analyze approaches classification and description chemical composition petroleum products and water-soluble mineral pollutants in soils. The main sources soil contamination with petroleum products, benz-a-pyrene and water-soluble mineral salts are identified. A comparative evaluation methods for determining total content petroleum products, determining residual amounts benz-a-pyrene and water-soluble inorganic pollutants soils urbanized territories was performed. Criteria selecting optimal physical and chemical methods quantitative determination petroleum products and mineral pollutants in soils are proposed. The method quantitative determination total content petroleum products in soils has been improved. It is shown that proposed method meets requirements expressiveness and allows us determine total content petroleum products in various types soils urbanized territories. The reliability proposed method proved by methods mathematical statistics. The residual amounts petroleum products, benz-a-pyrene, chlorides, phosphates and sulfates in soils selected in four different zones urbanized territories were determined. The residual amounts benz-a-pyrene were determined by high-performance liquid chromatography. Samples determination residual amounts benz-a-pyrene were prepared according original method-purified on a mixture aluminum oxide and sodium sulfate, elution was carried out with a hexano-chloromethylene mixture. The determination mass concentration chloride, sulfate and phosphate ions in soil samples (water-soluble form) by ion chromatography is considered using specific examples. The results studies were analyzed in accordance with the normalized indicators permissible content in soil for each type pollutants. It is shown that obtained data can be used as a basis for ecological monitoring soils urbanized territories for purpose predictive assessment prospects for their use.

Keywords: petroleum products, soil, urbanized territory, benz-a-pyrene, mineral pollutants, normalized indicators, environmental monitoring

Рост объемов промышленного производства на современном этапе развития общества напрямую связан с добычей и потреблением углеводородного топлива. Различные виды жидких топлив, представляющих отдельный тип нефтепродуктов, 
являются одним из основных источников загрязнения окружающей среды. При этом следует отметить, что потери нефтепродуктов, приводящих к загрязнению окружающей среды, оцениваются приблизительно десятью миллионами тонн в год [1].

При транспортировке, хранении нефтепродуктов, эксплуатации автомобильного транспорта и котельных, работающих на жидком топливе, происходит загрязнение атмосферы, гидросферы и литосферы. Загрязнение почвогрунтов нефтепродуктами следует отнести к особо опасным видам загрязнений, так как оно сопряжено с загрязнением гидросферы - попадая из почвогрунта в грунтовые и подземные воды, углеводороды уже при концентрациях 0,5 мг/л делают невозможным их использование в качестве питьевых [2].

В состав нефтепродуктов входит большое число органических веществ (углеводороды, ароматические соединения, гетероциклы) и неорганических веществ (неорганические соли и микроэлементы), которые оказывают прямое и косвенное биогеохимическое воздействие на почвогрунты. Поскольку нефтепродукты имеют многокомпонентный состав, их токсичность нельзя определить исходя из вклада в загрязнение отдельных соединений, так как одни из них могут деструктурировать другие, например в процессе окислительно-восстановительных процессов, протекающих под воздействием микроорганизмов. В связи с этим при загрязнении почвогрунтов нефтепродуктами целесообразно выделять следующие экологические факторы: многокомпонентность состава нефтепродуктов; динамику экосистемы; абиотические факторы среды (температура, давление, освещенность и др.) [3; 4]. Результатом суммарного действия указанных экологических факторов является частичная деструкция нефтепродуктов, в результате которой образуются органические кислоты, изменяющие химический состав почвогрунтов и обуславливающие рост минерализации поровой влаги.

Поэтому геоэкологический мониторинг загрязнения почвогрунтов нефтепродуктами имеет важное практическое значение, так как позволяет оценить степень их загрязнения, изменение ее во времени, а также служит основой прогнозной оценки использования загрязненных территорий.

Основу геоэкологического мониторинга загрязнения почвогрунтов нефтепродуктами составляют физико-химические методы, позволяющие определять суммарное содержание нефтепродуктов, сопутствующих особо опасных загрязнителей, таких как бенз-а-пирен и минеральные соли.

Так, например, для определения нефтепродуктов используют метод газовой хроматографии с применением детектора вакуумной ультрафиолетовой абсорбции (GC-VUV). Данный метод позволяет проводить определение по временным интервалам и обеспечивает высокую степень достоверности при идентификации совпадающих пиков в сложных углеводородных смесях. Метод изократической ВЭЖХ на колонке с неполярным гидрофобным сорбентом с детектором по поглощению света на 254 нм позволяет получать хроматографические фингерпринты нефтепродуктов и осуществлять процесс идентификации до того момента, когда она становится невозможной вследствие их деструкции [5]. Известны методы определения нефтепродуктов ИКфотометрией. Анализу предшествует экстракция нефтепродуктов из почвогрунта четыреххлористым углеводородом $\left(\mathrm{CCl}_{4}\right)$ [6]. Количественное определение бенз-а-пирена выполняют различными методами: методом низкотемпературной люминесценции, методом экстракции субкритической водой и др. Для количественного определения минеральных солей в почвогрунтах применяют методы капиллярного электрофореза, комплексонометрического определения и др. $[7 ; 8]$.

Следует отметить, что большинство применяемых в настоящее время методов определения нефтепродуктов, минеральных солей и бенз-а-пирена в загрязненных почвогрунтах характеризуются высокой стоимостью анализа, сложностью аппаратурного оформления, низким пространственным разрешением. В связи с этим совершенствование известных методов определения нефтепродуктов в почвогрунтах, поиск новых методов является актуальной задачей.

Цель работы заключалась в описании на конкретных примерах методологии определения остаточных количеств нефтепродуктов, бенз-а-пирена и водорастворимых минеральных загрязнителей в почвогрунтах урбанизированных территорий в рамках геоэкологического мониторинга для прогнозной оценки возможности их использования в хозяйственной деятельности.

\section{Материалы и методы исследования}

Определение остаточных количеств нефтепродуктов, бенз-а-пирена и мине- 
ральных солей в образцах почвогрунта выполняли в рамках геоэкологического мониторинга четырех районов г. Брянска и Брянской области с целью определения перспектив использования данных территорий в хозяйственной деятельности.

Пробы почвогрунта отбирали в соответствии с требованиями ГОСТ 17.4.4.02-2017.

Количественное определение суммарного содержания нефтепродуктов проводили с помощью усовершенствованной нами методики.

Бенз-а-пирен количественно определяли методом ВЭЖХ на флуориметрическом детекторе в соответствии с MUK 4.1.1274-03. Пробы почвогрунта подготавливали по оригинальной методике: очищали на смеси окиси алюминия и сульфата натрия, элюирование проводили гексано-хлористометиленовой смесью.

Определение массовой доли хлоридов, сульфатов, фосфатов в образцах почвогрунта (водорастворимая форма) проводили методом ионной хроматографии в соответствии с РД 52.18.572-96.

Прогнозную оценку возможности использования загрязненных территорий в хозяйственной деятельности выполняли с учетом СП 11-102-97.

Статистическую обработку результатов анализа проводили с использованием программы Mathcad.

\section{Результаты исследования и их обсуждение}

В соответствии с поставленными задачами на первоначальном этапе нами были проведены теоретические исследования, в ходе которых были проанализированы подходы к классификации нефтепродуктов и выделены основные источники загрязнения почвогрунтов нефтепродуктами.

За основу нами была выбрана иерархическая классификация нефтепродуктов, регламентированная ГОСТ 26098-84. В соответствии с данным источником нефтепродукты подразделяют на типы, группы, подгруппы, марки и сорта. При этом следует отметить, что в один тип объединяются нефтепродукты одинакового функционального назначения. Группа и подгруппа включают нефтепродукты, имеющие сходные свойства, показатели качества и области применения. Марка и сорт нефтепродуктов соответствуют индивидуальным нефтепродуктам, свойства и показатели качества которых регламентированы нормативно-технической документацией.
Поскольку в рамках данной работы выполнялось определение остаточных количеств нефтепродуктов в образцах почвогрунта, целесообразно взять за основу их тип, так как невозможно оценить по отдельности вклад группы, подгруппы, а тем более марки и сорта, в общее загрязнение территории.

Поскольку тип нефтепродуктов включает весь спектр потенциальных загрязнителей, целесообразно определять суммарное остаточное содержание нефтепродуктов в образцах почвогрунта, не подразделяя их на более узкие категории.

Выбор методов количественного контроля нефтепродуктов в почвогрунтах напрямую связан с определением источника загрязнения, так как от последнего зависит характер и степень загрязнения. В соответствии с данными [9] основными источниками загрязнения природных сред нефтепродуктами являются предприятия по нефтедобыче, производству, хранению и транспортировке нефтепродуктов, автомобильный транспорт, а также котельные, вырабатывающие тепловую энергию в результате сжигания жидкого углеводородного топлива. Отмечается, что атмосферный перенос следует выделять как отдельный источник загрязнения окружающей среды нефтепродуктами. Вклад данного источника в общее загрязнение обусловлен неполным сгоранием жидких нефтяных топлив, поступлением нефтепродуктов и особо опасных веществ, например бенз-а-пирена, в атмосферу. В газообразном состоянии нефтепродукты могут находиться в атмосфере от полугода до двух лет, попадая затем в почву. Так как в настоящей работе объектом исследования являются почвогрунты урбанизированной территории, то в качестве основных источников загрязнения целесообразно рассматривать предприятия по хранению, транспортировке нефтепродуктов, источники сжигания жидких нефтяных топлив и атмосферный перенос. Поскольку перечисленные источники загрязняют окружающую среду к тому же и неорганическими соединениями, например минеральными солями, нами также было проведено количественное определение данных соединений в образцах почвогрунта.

В качестве объекта исследования нами были выбраны почвогрунты четырех районов г. Брянска и Брянской области. Точки пробоотбора расположены в пределах урбанизированных территорий и характеризуются следующими особенностями: участок 
1 - территория, прилегающая к нефтебазе (расстояние $450 \mathrm{~m}$ ); участок 2 - территория, граничащая с автозаправочной станцией (расстояние $150 \mathrm{~m}$ ); участок 3 - территория реконструкции аэропорта (расстояние 700 м); участок 4 - территория, примыкающая к автомобильной дороге (расстояние 350 м) (рис. 1).

В пределах каждого участка было отобрано по три усредненных образца почвогрунта с различной глубины: $0.2,0.5,1$ м. Образцы проб почвогрунта были последовательно пронумерованы.

В ходе общего физического анализа и классификации установлено, что образцы, отобранные с участка 1, представляют несвязанный минеральный грунт (песок), содержащий включения твердых коммунальных отходов. Основным компонентом почвогрунта с участков 2, 3, 4 является суглинок.

В соответствии с принципами выбора методов исследования [6;10] нами была усовершенствована методика определения суммарного количества нефтепродуктов в почвогрунтах. Методика основана на измерении массовой доли нефтепродуктов в почвогрунтах флуориметрическим методом. В качестве анализатора исполь- зовали «ФЛЮОРАТ-02». Для определения брали навеску подготовленной пробы почвогрунта массой 1 г. Нефтепродукты экстрагировали гексаном в течение 15 минут при перемешивании и определяли на флюорате значение в мВ, соответствующее аликвоте полученного экстракта. Данное значение использовали в последующем расчете содержания нефтепродуктов в образце почвогрунта. Методика позволяет определять массовые доли нефтепродуктов в диапазоне 5-20000 мг/кг. Достоверность предлагаемой методики подтверждена статистическими методами (рис. 2).

Из данных, представленных на рис. 2, видно, что усовершенствованная нами методика характеризуется высокой степенью сходимости с известной методикой ПНД Ф 16.1:2.21-98. Рассчитанный коэффициент корреляции составил 0,94, что свидетельствует о высокой степени достоверности. Также следует отметить, что предлагаемая методика позволяет упростить ход анализа и отвечает требованиям экспресс-анализа и может быть использована в процессе геоэкологического мониторинга.

Данные по определению суммарного содержания нефтепродуктов и бенз-а-пирена представлены в таблице.

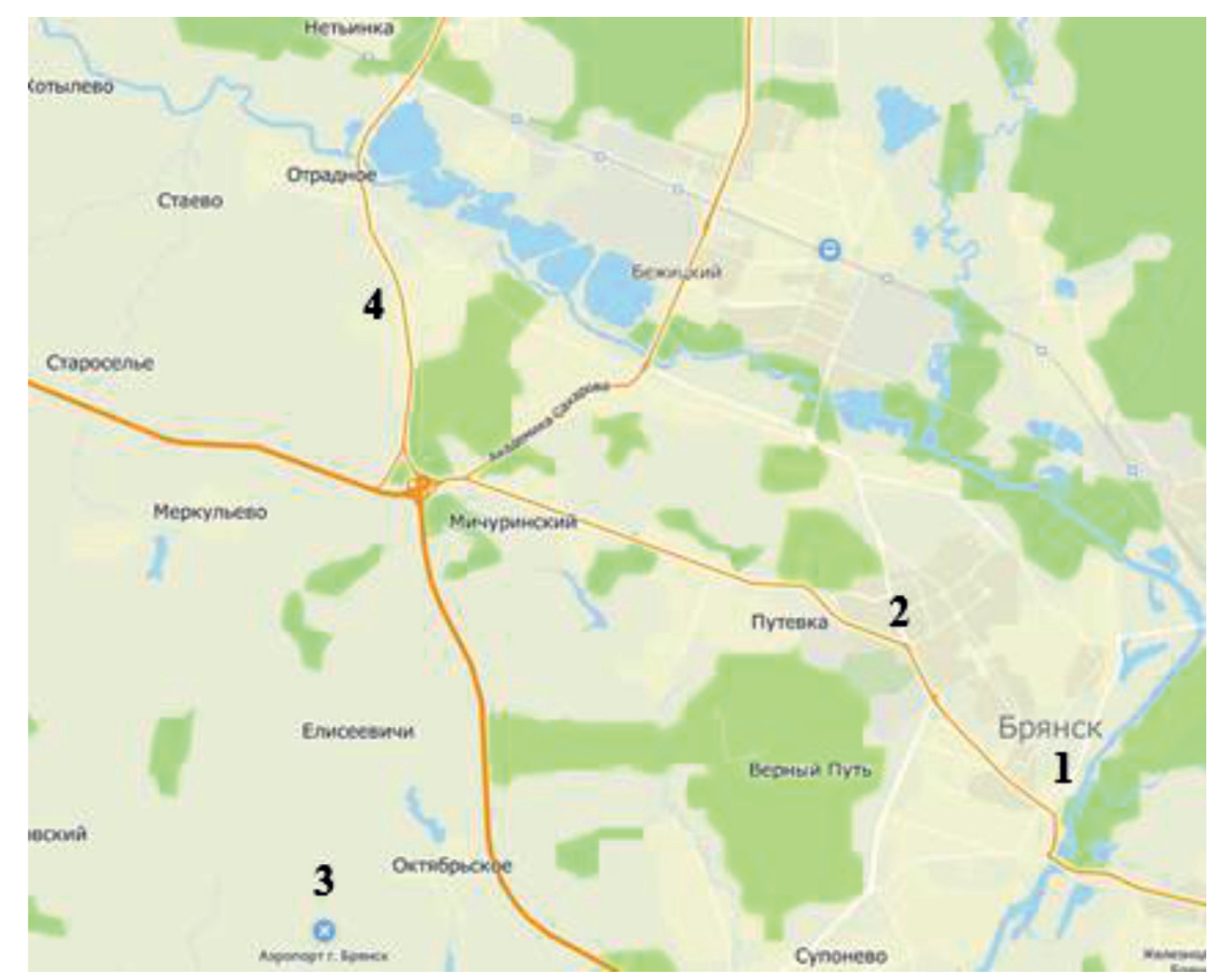

Рис. 1. Участки отбора почвогрунтов 


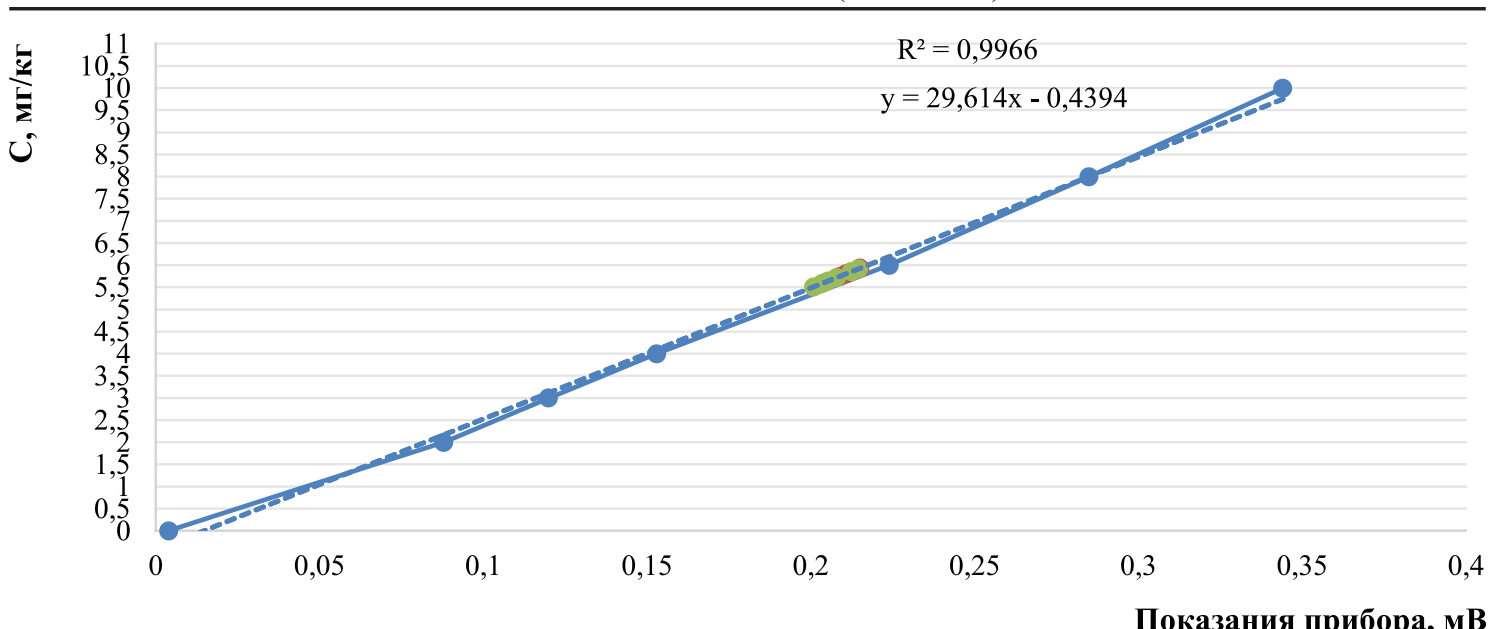

- Значения концентации нефтепродуктов серии стандартов

- - Значения концентраций нефтепродуктов, определенные по ПНДФ

- Значения концентраций нефтепродуктов, определенные по усовершенствованной методике

Рис. 2. Результаты определения кониентрации нефтепродуктов в образцах почвогрунта различными методиками в сравнении с серией стандартов

Суммарное содержание нефтепродуктов и бенз-а-пирена в образцах почвогрунта

\begin{tabular}{|c|c|c|c|c|c|}
\hline \multirow[t]{2}{*}{ № пробы } & \multicolumn{2}{|c|}{ Содержание, мг/кг } & \multirow[t]{2}{*}{ № пробы } & \multicolumn{2}{|c|}{ Содержание, мг/кг } \\
\hline & нефтепродуктов & бенз-а-пирена & & нефтепродуктов & бенз-а-пирена \\
\hline 1 & 7,3 & $<0,005$ & 7 & 125,4 & 0,012 \\
\hline 2 & 7 & $<0,005$ & 8 & 125,1 & 0,012 \\
\hline 3 & 6,9 & $<0,005$ & 9 & 124,7 & 0,010 \\
\hline 4 & 31,9 & 0,007 & 10 & 312 & 0,014 \\
\hline 5 & 31,6 & 0,006 & 11 & 307 & 1,013 \\
\hline 6 & 30,9 & $<0,005$ & 12 & 303 & 0,010 \\
\hline
\end{tabular}

Допустимые концентрации бенз-апирена в образцах почвогрунта оценивали по ГН 2.1.7.2041-06, в соответствии с которыми ПДК бенз-а-пирена составляет 0,02 мг/кг. На основании данных, представленных в таблице, можно сделать вывод, что наименьшее содержание данного вещества (0,005-0,007 мг/кг) наблюдается в пробах почвогрунта с участка № 1 (пробы $1,2,3$ ) и участка № 2 (пробы $4,5,6$ ). По-видимому, это связано с тем, что данные участки удалены от автомобильных магистралей. Более высокие концентрации бенз-а-пирена (от 0,010 до 0,014 ) выявлены в переделах участков № 3 (пробы $7,8,9$ ) и № 4 (пробы $10,11,12)$. По нашему мнению, это можно объяснить расположением данных территорий вблизи аэропорта и автомобильной дороги соответственно, так как загрязнение бенз-а-пиреном почвогрунтов происходит за счет продуктов сгорания топлива. В пределах участка № 1 содержание бенза-пирена равномерно распределено по всей глубине и составляет $<0,005$ мг/кг, тогда как на участках № № 2, 3, 4 более высокие концентрации наблюдаются в верхних слоях почвогрунта на глубине 0,2 м. Выявленную закономерность можно объяснить природой почвогрунта: в пределах участков № № 2, 3 и 4 основным компонентом почвогрунта является суглинок, что препятствует миграции бенз-а-пирена по глубине. Вместе с тем следует отметить, что концентрация бенз-апирена в пределах обследованных участков не превышает ПДК.

По данным [6], для нефтепродуктов предельно допустимая концентрация не установлена, это связано с тем, что нефтепродукты содержат в своем составе соединения, которые характерны для различных типов почв. В настоящее время уровни загрязненности земель нефтью и нефтепродуктами определяются [11], на основании которого можно сделать вывод, что загрязнение почвогрунтов обследуемых территорий нефтепродуктами не превышает фоновых значений. 


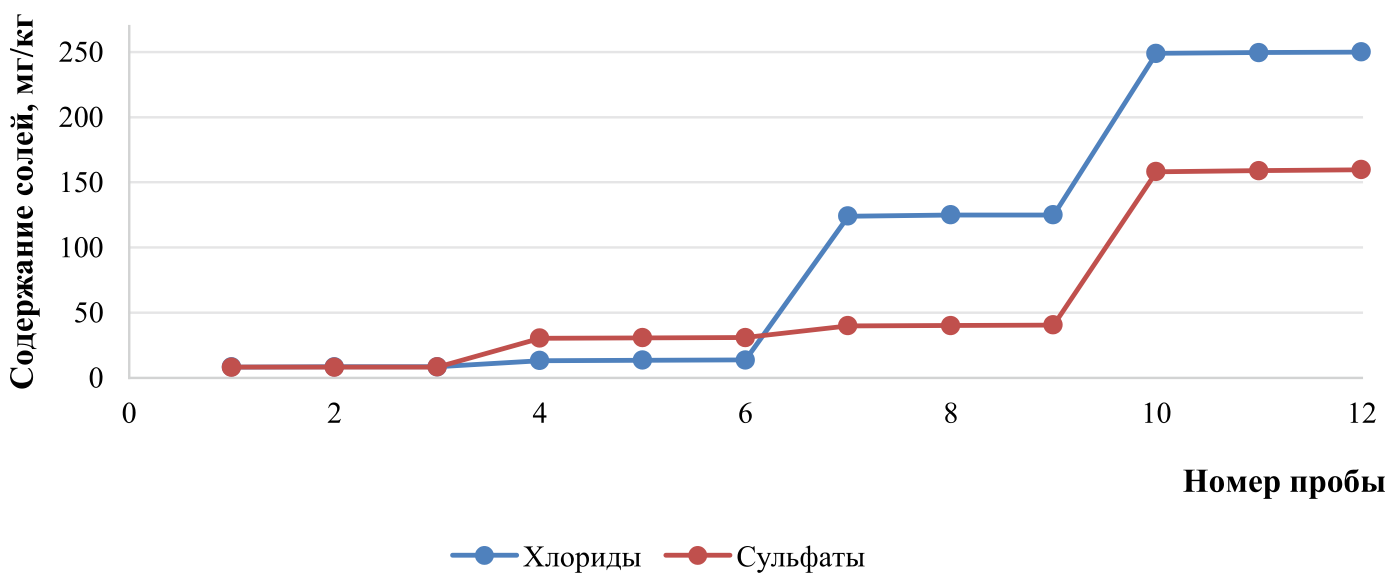

Рис. 3. Содержание минеральных солей в образцах почвогрунта

Данные по определению количественного содержания минеральных солей в образцах исследуемого почвогрунта представлены на рис. 3.

Предельно допустимые концентрации хлоридов, сульфатов и фосфатов в соответствии с ГН 2.1.7.2041-06 в почвогрунтах составляют соответственно 360, 160 и 200 мг/ кг. Содержание фосфатов во всех исследуемых образцах почвогрунта не превысило 1 мг/кг. Из данных, представленных на рисунке 3 , следует, что максимальное содержание хлоридов установлено в пределах участка № 4 (250 мг/кг), что объясняется расположением данной территории рядом c автомобильной дорогой. Содержание сульфатов (в пересчете на элементарную серу) находится в пределах ПДК.

Таким образом, по результатам проведенного анализа почвогрунтов на содержание нефтепродуктов и минеральных солей можно сделать вывод, что с учетом содержания данных загрязнителей в почвогрунте территории обследуемых участков пригодны для промышленной или жилищной застройки.

\section{Выводы}

Проанализированы подходы к классификации и описанию химического состава нефтепродуктов и водорастворимых минеральных загрязнителей почв. Обосновано выделение основных источников загрязнения почв нефтепродуктами, бенз-а-пиреном и водорастворимыми минеральными солями.

На конкретном примере описана методология определения остаточных количеств нефтепродуктов, бенз-а-пирена и водорастворимых минеральных загрязнителей в почвогрунтах урбанизированных территорий.
Усовершенствованы методики определения суммарного содержания нефтепродуктов в образцах почвогрунта и подготовки проб при анализе бенз-а-пирена.

Предлагаемый подход определения содержания нефтепродуктов, бенз-а-пирена и минеральных солей в почвогрунтах может быть использован в рамках геоэкологического мониторинга для прогнозной оценки возможности их использования в хозяйственной деятельности.

\section{Список литературы}

1. Тимергазина И.Ф., Переходова Л.С. К проблеме биологического окисления нефти и нефтепродуктов углеводородоокисляющими микроорганизмами // Нефтегазовая геология. Теория и практика. 2012. № 1. C. 1-28.

Timergazina I.F., Perekhodova L.S. On the problem of biological oxidation of oil and petroleum products by hydrocarbonoxidizing microorganisms // Neftegazovaya geologiya. Teoriya $\mathrm{i}$ praktika. 2012. № 1. P. 1-28 (in Russian).

2. Титов К.В., Ильин Ю.Т., Коносавский П.К., Муслимов А.В., Рыбальченко О.В., Орлова О.Г., Мено А. Изменение физических свойств загрязненного нефтепродуктами песка при бактериальном воздействии // Геоэкология. Инженерная геология. Гидрогеология. Геокриология. 2012. № 5. С. 455-469.

Titov K.V., Ilyin Yu.T., Konosavsky P.K., Muslimov A.V., Rybalchenko O.V., Orlova O.G., Meno A. Changes in the physical properties of sand contaminated with petroleum products under bacterial exposure // Geoekologiya. Inzhenernaya geologiya. Gidrogeologiya. Geokriologiya. 2012. № 5. P. 455-469 (in Russian).

3. Гаджиев Н.Г., Гакаев Р.А. Внедрение культурных фитоценозов с целью улучшения состояния нарушенных почв (на примере Чеченской Республики) // Актуальные проблемы экологии и природопользования: сборник научных трудов (Москва, 10-12 апреля 2014 г.). М.: РУДН, 2014. С. 227-230.

Gadzhiev N.G., Gakaev R.A. Introduction of cultural phytocenoses to improve the state of disturbed soils (on the example of the Chechen Republic). In the collection // Aktual'nyye problemy ekologii i prirodopol'zovaniya: sbornik nauchnykh trudov (Moskva, 10-12 aprelya 2014 g.). M.: RUDN, 2014. P. 227-230 (in Russian).

4. Гакаев Р.А. Биоэкологические особенности реабилитации почв, загрязненных нефтью и нефтепродуктами // Биоэкономика и экобиополитика. 2016. № 1 (2). С. 216-218.

Gakaev R.A. Bioecological features of rehabilitation of soils contaminated with oil and petroleum products // Bioekonomika i ekobiopolitika. 2016. № 1 (2). P. 216-218 (in Russian). 
5. Астахов А. Анализ нефтепродуктов с помощью хроматографических методов // Аналитика. 2013. № 3. С. 48-52.

Astakhov A. Analysis of petroleum products using chromatographic methods // Analitika. 2013. № 3. P. 48-52 (in Russian).

6. Околелова А.А., Капля В.Н., Лапченков А.Г. Оценка содержания нефтепродуктов в почвах // Научные ведомости. Серия: Естественные науки. 2019. Т. 43. № 1. С. 76-86.

Okolelova A.A., Kaplya V.N., Lapchenkov A.G. Assessment of the content of petroleum products in soils // Nauchnyye vedomosti. Seriya: Yestestvennyye nauki. 2019. Vol. 43. № 1 . P. 76-86 (in Russian).

7. Сушкова С.Н., Минкина Т.М., Назаренко О.Г., Манджиева С.С., Лекарь А.В. разработка метода экстракции 3,4-бенз(а)пирена из почв субкритической водой // Плодородие. 2012. № 3. С. 44-46.

Sushkova S. N., Minkina T. M., Nazarenko O. G., Mandzhieva S. S., Lekar A.V. Development of a method for extracting 3,4-benz (a)pyrene from soils with subcritical water // Plodorodiye. 2012. № 3. P. 44-46 (in Russian)

8. Каменцев М.Я., Мамедова С.Н., Москвин Л.Н., Якимова Н.М. Определение хлорид- и сульфат-ионов в воде высокой чистоты методом капиллярного электрофореза // Журнал аналитической химии. 2015. Т. 70. № 2. C. 169-173.

Kamentsev M.Ya., Mamedova S.N., Moskvin L.N., Yakimova N.M. Determination of chloride and sulfate ions in high- purity water by capillary electrophoresis // Zhurnal analiticheskoy khimii. 2015. Vol. 70. № 2. P. 169-173 (in Russian).

9. Хаустов А.П., Редина М.М. Трансформация нефтепродуктов как источник токсичных загрязнений природных сред // Экология и промышленность России. 2012. № 12. С. 38-44.

Khaustov A.P., Redina M.M. Transformation of petroleum products as a source of toxic pollution of natural environments // Ekologiya i promyshlennost' Rossii. 2012. № 12. P. 38-44 (in Russian).

10. Лукашов С.В., Иванченкова О.А. Анализ состояния почвогрунтов урбанизированной территории как элемент инженерно-экологических изысканий // Успехи современного естествознания. 2020. № 5. С. 56-62.

Lukashov S.V., Ivanchenkova O.A. Analysis of the state of soils of urbanized territories as an element of engineering and environmental surveys // Uspekhi sovremennogo yestestvoznaniya. 2020. № 5. P. 56-62 (in Russian).

11. Акт правительства Российской Федерации «Порядок определения размеров ущерба от загрязнения земель химическими веществами» от 27 декабря 1993 № 04-25, № 61-5678 [Электронный ресурс]. URL: https://docs.cntd.ru/ document/9033369 (дата обращения: 15.03.2021).

Act of the Government of the Russian Federation «Procedure for determining the amount of damage from land pollution by chemical substances» dated December 27, 1993 № 04-25, № 61-5678 [Electronic resource]. URL: ttps://docs.cntd.ru/document/9033369 (date of access: 15.03.2021) (in Russian). 